\title{
A MÚSICA E AS ARTES AUXILIANDO O DESENVOLVIMENTO HUMANO ${ }^{1}$
}

\section{MUSIC AND ARTS HELPING HUMAN DEVELOPMENT}

\author{
Sonia Regina Albano de Lima \\ Universidade Estadual Paulista \\ soniaalbano@vol.com.br
}

\section{Resumo}

São muitas as pesquisas que demonstram de que forma as Artes e o ensino artístico atuam no desenvolvimento psíquico, físico, sociocultural, mental e estético dos indivíduos. No que concerne ao cenário musical mais especificamente, pesquisas realizadas por A. Storr, J. Sloboda, H. Gardner, L. Meyer, entre outros, relatam o caráter ordenatório desta linguagem, a ligação que ela estabelece com o corpo humano, o seu efeito sensibilizador, a experiência emocional e estética que ela abriga. Esse trabalho investigativo traz para essa arte um sentido e função que transcende o caráter puramente estético que ela contempla, constituindo-se em uma linguagem integrada às demais linguagens, capaz de contribuir de forma benéfica na evolução integral dos indivíduos. Assim, a inclusão do ensino musical na educação básica, nos cursos de formação de docente e na educação informal sob diferentes propostas e condições torna-se uma medida salutar para a evolução humana.

Palavras-chave: música; desenvolvimento humano; ensino musical; educação formal; educação informal.

I $\bigcirc$ texto resume parte da sua tese de pós-doutoramento realizado no IA-UNESP. 


\section{Abstract}

Many are the researches that demonstrate the way Arts and the artistic teaching act in the individuals' psychic, physic, socio-cultural, mental and aesthetic development. More specifically, in relation to the musical setting, research carried out by A. Storr, J. Sloboda, H. Gardner, L. Meyer, among others, report the ordinance character of this language, the link it sets up with the human body, its sensitizing effect, the emotional and aesthetic experience it shelters. This investigative work brings to this art meaning and function which transcends the purely aesthetic character that it contemplates, setting itself up as a language which is integrated to the other ones, capable of contributing in a beneficial way to the individuals' integral evolution. Thus, the inclusion of the musical teaching in the basic education, in the courses of qualification for teachers, and in the informal education under different proposals and conditions becomes a healthful measure for the human evolution.

Keywords: Music; human development; musical teaching; formal education; informal education.

Na atualidade são poucas as instituições de ensino formal brasileiro que tem trabalhado a música como uma linguagem auxiliar para o desenvolvimento psíquico, social, mental e físico do indivíduo. Essa nobre função tem sido priorizada por algumas instituições de ensino não formal e pelas ONGs, muitas delas, desenvolvendo trabalhos pedagógico-musicais voltados para a educação especial e para as crianças e jovens em situação de risco social. Nestes organismos vislumbra-se um ensino musical com vistas ao aprimoramento da percepção, da sensibilidade, da concentração, da sociabilidade, da coordenação corporal, da afetividade, da disciplina, das emoções, ou um ensino para crianças e jovens que não teriam condições monetárias de aprender um instrumento e almejam obter esse aprendizado.

No texto que se segue é nossa intenção apontar os benefícios advindos de um ensino musical que contribuiu para 0 aprimoramento humano em todas as dimensões (sociais, cognitivas, psíquicas, neurológicas, físicas e estéticas). Nesse sentido, pesquisas 
desenvolvidas por pesquisadores de outras áreas de conhecimento têm contribuído para esse avanço. Psicólogos, médicos, físicos, sociólogos, antropólogos e educadores têm mensurado os fatos e fenômenos importantes circunscritos à música, a partir de testes diversos e exames neurofisiológicos. Estes experimentos trazem para a música uma função sociocultural e humanitária importante, fato que justifica a sua inclusão na educação básica e nos cursos de formação de docentes.

A inclusão da música no ambiente educacional, principalmente na educação básica, traz de volta parte da função a ela destinada pelos antigos gregos. Nesse período, além do seu valor estético, a música tinha um sentido fisiológico, ético e era considerada componente importante para a formação da personalidade humana (LIMA, 2007). Platão via na música um elemento essencial para a educação do indivíduo. Para ele todos os gregos deveriam aprender música. A teoria ética da música desenvolvida pelo filósofo Damon e, mais tarde aprimorada por Platão, acreditava que a virtude podia ser ensinada e a música, quando utilizada de modo correto, era um dos meios mais idôneos para se atingir esse objetivo (FUBINI, 1999, p. 59).

Distanciados que estamos do sentido grego atribuido à música e considerados os avanços tecnológicos, a diversidade cultural e as transformações socioculturais ocorridas nas últimas décadas, cumprenos refletir, na atualidade, de que maneira a música pode contribuir para o desenvolvimento bio/psíquico/social dos indivíduos; como ela pode colaborar na solução dos problemas emergentes presentes em nossa sociedade e em que medida ela estaria concorde aos interesses educacionais e das políticas públicas que norteiam nossa Educação.

Alguns educadores musicais e profissionais da música têm se empenhado em demonstrar os benefícios, as potencialidades e os aprimoramentos cognitivos que essa linguagem pode proporcionar para os indivíduos, principalmente, para as crianças e jovens. Entre eles cito o compositor e educador musical H. J. Koellreutter, que dedicou boa parte de sua vida para demonstrar a importância de se introduzir em nosso país um ensino musical diferenciado do modelo tecnicista adotado nas escolas de música brasileiras, pensando a música como uma atividade artística a serviço da sociedade: 
Como instrumento de libertação, a arte torna-se um meio indispensável de educação, pelo fato de oferecer uma contribuição essencial à formação do ambiente humano. Assim, através de sua integração na sociedade, a arte torna-se um traço central da sociedade moderna, desde que, por meio desta sua integração, ela vença sua alienação social e sobreviva à sua crise. [...] (os musicistas) deverão estar capacitados a encarar sua arte como arte aplicada, isto é, como um complemento estético aos vários setores da vida e da atividade do homem moderno. [...] musicistas que deverão estar preparados para colocar suas atividades a serviço da sociedade (KOELLREUTTER apud KATER, 1997, p. 38-39).

Koellreutter, em diversos momentos, buscou demonstrar o quanto os currículos das escolas e universidades de ensino musical estavam afastados da realidade sociocultural brasileira e de um questionamento crítico direcionado para o sistema educacional vigente.

Se nos concentrarmos em relatos produzidos pelos pesquisadores contemporâneos da Educação, vamos observar que eles pregam continuadamente um agir pedagógico que possibilite a compreensão de como os fatores socioculturais e institucionais atuam nos processos de transformação dos sujeitos, em que condições esses sujeitos aprendem melhor e em que medida o ensino deve se afastar de um modelo de aprendizagem tecnicista. José Carlos Libâneo é um deles:

Escola existe para formar sujeitos preparados para sobreviver nesta sociedade, para isso, precisam da ciência, da cultura, da arte, precisam saber coisas, saber resolver dilemas, ter autonomia e responsabilidade, saber dos seus direitos e deveres, construir sua dignidade humana, ter uma autoimagem positiva, desenvolver capacidades cognitivas para se apropriar criticamente dos benefícios da ciência e da tecnologia em favor do seu trabalho, da sua vida cotidiana, do seu crescimento pessoal. Mesmo sabendo-se que essas aprendizagens impliquem em saberes originados nas relações cotidianas e experiências socioculturais, isto é, a cultura da vida cotidiana (LIBÂNEO; SANTOS, 2005, p. 21). 
Libâneo admite que as teorias pedagógicas modernas, apesar de inúmeras e bastante específicas, possuem características que demandam uma reavaliação. Nesse sentido é importante o educador rever conceitos que veiculam a acentuação da atividade racional, científica, tecnológica como objetos de conhecimento e as atuações pedagógicas que transmitem o conhecimento e modos de ação de uma pretensa cultura universal que deve ser comunicada às novas gerações e recriada continuadamente, com o intuito de obter continuidade:

\begin{abstract}
É importante que os professores da atualidade não aceitem como um dado incontestável, que os indivíduos tenham uma natureza humana básica advinda dos direitos universais e que eles, enquanto docentes, sejam os representantes legítimos dessa cultura, fazendo com que seus alunos internalizem valores universais, seja pela intervenção pedagógica direta seja pelo esclarecimento de valores em âmbito pessoal (LIBÂNEO; SANTOS, 2005).
\end{abstract}

pesquisador relata que, em função de privilegiarmos uma razão voltada quase que inteiramente para o cientificismo, as teorias pedagógicas modernas abafam os sentimentos, a imaginação, a subjetividade e a liberdade. $\bigcirc$ acúmulo de conhecimentos científicos e técnicos trazidos pela modernidade faz surgir diversos campos disciplinares, no entanto, esses saberes permanecem isolados, fragmentados, ignoram o conjunto de que fazem parte e o significado que thes é destinado na soma de saberes.

Nessa modalidade de ensino há uma preocupação excessiva com a formação técnico profissional, o educador não precisa promover a contextualização filosófica do conhecimento a ser ensinado, apenas a sua contextualização imediata. Este modelo de ensino enfatiza a técnica, o saber fazer suficiente para uma determinada profissão, sem questionamentos adicionais nem aprofundamentos no conhecimento como um todo. Dessa forma, cultura, economia, política, sistema de valores e personalidade humana são saberes estudados isoladamente e de forma dissociada, contrariando o sentido maior da Educação.

Afastam-se desta fórmula pedagógica as discussões teóricas que verificam quais os objetivos educacionais e as competências que este aprendizado deve alcançar; o conceito de conhecimento como uma 
rede de relações; o princípio da não hierarquia dos conhecimentos. Nele os interesses macrossociais prevalecem sobre os microssociais (LIBÂNEO; SANTOS, 2005).

Libâneo entende que as mudanças no agir pedagógico são mais do que necessárias, considerando-se o conjunto de condições sociais, culturais e econômicas que estão afetando todas as instâncias da vida social. Nesta nova realidade os educadores devem ajudar os estudantes a construírem seus próprios valores a partir das suas culturas e cultivar a diversidade, a tolerância, a liberdade, a criatividade, as emoções e a intuição.

A educadora Maria Cândida Moraes também vê com bons olhos a remodelação na educação atual, considerando que o mundo contemporâneo trabalha em rede:

Realidade e mundo, como totalidades enredadas, estrutural e funcionalmente, também repercutem e afetam o trabalho docente, o planejamento curricular, os processos de ensino e de aprendizagem, os papéis desempenhados por alunos e professores e a dinâmica das infraestruturas educacionais. Ao mesmo tempo, exigem novas competências e habilidades para continuar aprendendo ao longo da vida. Nesse mundo enredado, é importante aprender a viver/conviver com as diferenças, compreender a diversidade e as adversidades, reconhecer a pluralidade e as múltiplas realidades, ter abertura, respeito e tolerância em relação às formas de pensar, de ser e de viver de cada um (MORAES, 2008, p. 15-16).

Para o futuro essa pesquisadora relata que a educação deve adotar os seguintes comportamentos: a contextualização; o diálogo entre a teoria e a prática; a integração do pensamento, do sentimento e do corpo e a religação do indivíduo com a sociedade e a natureza. Sob este prisma, a expressão artística tem um papel fundamental exteriorizar emoções e sentimentos, muitas vezes indiziveis:

[...](a expressão artística) traz à consciência aspectos internos para serem refletidos e podem ser recursos para 
o autoconhecimento. Ao se concentrar na elaboração de uma obra de arte o aluno trabalha criativamente, num diálogo recursivo consigo próprio. É, portanto, mais um espaço dedicado à convivência consigo mesmo (lbid, p. 272).

Ela relata que o ser humano ao entrar em contato com suas emoções, sentimentos e o seu interior, nutre-se das correntes de energia que circulam o corpo. As emoções e os sentimentos criam espaços operacionais que influenciam as reflexões e ações humanas, podendo potencializar ou dificultar a capacidade de aprendizagem, incentivando ou restringindo o domínio de ação do aprendiz e o operar de sua inteligência. Sendo assim, as emoções e os sentimentos podem expandir ou restringir a capacidade operacional dos indivíduos, tanto no que se refere às possibilidades de reflexão quanto de atuação. Cabe, então, ao educador, criar espaços mais propícios à reflexão e à ação. Espaços agradáveis, acolhedores, criativos e não competitivos: "espaços emocionalmente sadios que valorizam o FAZER em contínuo diálogo com O SER. Potencializando O FAZER, estaremos também potencializando o SER" (Ibid, p. 165).

Nessa fala está contida a importância que Moraes destina ao ensino das artes. Ela admite que trabalhar os conteúdos de aprendizagem com diálogos multissensoriais que utilizam diversas linguagens e estímulos - como os visuais, musicais, verbais, táteis, cinéticos, entre outros - promove a sincronização lúdica e empática entre os docentes, discentes e os conteúdos trabalhados. Esses diálogos multissensoriais ajudam e facilitam a compreensão da multidimensionalidade humana por parte do sujeito aprendiz (MORAES, 2008, p. 166).

Também Howard Gardner, em suas publicações (1994, 1997, 1999), tem se preocupado em demonstrar os benefícios oriundos de um ensino artístico sensibilizador. Ao investigar o funcionamento da inteligência humana, os processos de percepção, criatividade e os mecanismos de simbolização, Gardner vê no aprendizado das artes uma possibilidade do indivíduo se desenvolver cognitivamente em múltiplas dimensões:

Sin embargo, la habilidad artística humana se enfoca primero y ante todo como una actividad de la mente, como una actividad que involucra el uso y la transformación de 
diversas clases de símbolos e de sistemas de símbolos. Los indivíduos que quieren participar de un modo significativo en la percepción artística tienen que aprender a descodificar, a "leer" los diversos vehículos simbólicos presentes en su cultura; los indivíduos que quieren participar en la creación artística tienen que aprender de qué modo manipular, de qué modo "escribir con" las diversas formas simbólicas presentes en su cultura; y, por último, los indivíduos que quieren comprometerse plenamente en el ámbito artístico tienen que hacerse también con el domínio de determinados conceptos artísticos fundamentais (CARDNER, 1994, p. 30).

grande legado de Gardner para a Educação Artística concentra-se nas pesquisas realizadas com o intuito de conhecer os processos cognitivos que circundam o fazer artístico e seus símbolos como um todo. Ele vê no ensino das Artes uma das formas de o homem se comunicar com o mundo e um meio de auxiliar o indivíduo a compreender o universo sob uma perspectiva estética, simbólica e subjetiva.

Os relatos e pesquisas produzidas por Gardner confirmam o fato de que as Artes e a Música contribuem beneficamente para o desenvolvimento integral e pleno dos indivíduos. Para ele a música acarreta habilidades na atuação, na composição e na apreciação de padrões musicais, entre elas: habilidades de apreciação da melodia e da harmonia, a sensibilidade ao ritmo, a capacidade de reconhecer variações no timbre e na tonalidade e a capacidade de captar a estrutura do funcionamento da música. Contudo, ela não é apenas racionalidade, ela tem suas implicações emocionais e exerce efeitos sobre os indivíduos. Ela pode comunicar emoções e captar formas destes sentimentos.

As publicações e os projetos de pesquisa desenvolvidos por Gardner e seus parceiros objetivam provar que a educação artística é um campo propício para o desenvolvimento de outras habilidades cognitivas diferentes das alfanuméricas e da linguística-predominantes durante muito tempo nas análises psicológicas envolvendo o conceito de inteligência. Os artistas, ao invés de operarem com essas duas inteligências, utilizam diversas formas de representação mental capturadas em uma variedade de sistemas simbólicos tradicionais e inovadores. Mesmo assim é bom que se diga que a linguagem musical conserva inúmeras inter-relações com a matemática e a retórica. 
O livro de Oscar João Abdounur, intitulado Matemática e Música (1999), relata as relações que se estabeleceram entre a música e a matemática no decorrer dos séculos. A Música encontra na Matemática uma forma de desenvolvimento analógico que the permite a melhor compreensão de suas correspondências, de suas afinidades estruturais e sensoriais (LIMA, 2007, p. 34).

É bom que se diga que na Grécia Antiga o estudo da harmonia musical era prioritário para compreender de que forma a estrutura matemática, racional e ordenada do Universo se revelava na estrutura acústica, física e sensivel da música.

A par de sua inter-relação com a matemática e a retórica (LIMA, 2005, 201 1), o nosso texto vai verificar mais atentamente como a música pode contribuir de forma benéfica para o desenvolvimento integral dos indivíduos. Nesse sentido os relatos e pesquisas empíricas realizadas por Anthony Storr, John Sloboda, Leonard Meyer, extrapolam modelos de pesquisas educacionais adstritos a avaliação de metodologias de ensino, procedimentos pedagógicos, diários de campo e outras atividades pedagógicas vivenciadas em sala de aula. Os resultados alcançados com esses trabalhos trazem um avanço considerável para a área.

psicólogo A. Storr ao discorrer sobre os fenômenos musicais, afirma que as razões pelas quais a música afeta o homem estão justamente no seu poder de estruturar a experiência auditiva e, não tanto, no fato dela possibilitar a comunicação das emoções e da subjetividade humana. Para ele, a música não comunica de forma direta os sentimentos do compositor; ela é a forma do compositor comunicar ao mundo como ele deu sentido às suas emoções, como as estruturou, ou como transformou em arte seus sentimentos:

Cuando participamos de la música o escuchamos una interpretación que nos embelesa, nos aislamos, de forma temporal, de otros estímulos externos. Entramos en un mundo especial y apartado donde prevelece el orden y las incongruencias no tienen cabida. [...] Se trata de un "retiro" temporal que facilita un proceso de reordenación mental, lo cual propicia la adaptación al mundo exterior y no constituye una vía de escape (STORR, 2002, p. 139). 
Storr admite que a formação de novos padrões cognitivos é uma atividade mental contínua para os homens e se processa até no inconsciente. Essa atividade mental está presente tanto nas teorias científicas como nas obras de arte:

Sin embargo, cuando distinguimos una conexión inesperada, un nuevo patrón, experimentamos una profunda satisfacción. [...] cuando se descubre un nuevo esquema, este suele tener mucha importancia para el descubridor, así como para todos los que lo comprenden y aprecian. Esto es válido no solo para teorias científicas y otros intentos intelectuales por encontrar un sentido al universo, sino también para las obras de arte que son algo más que una mera repetición de sus precursoras. Y exclamamos "Eureka!" ante el placer de descubrir una nueva Gestalt, aunque ésta no tenga una aplicación cotidiana imediata (lbid, p. 221).

Ao referendar D. E. Berlyne, Storr relata que o objetivo de toda atividade intelectual, incluída a ciência, a filosofia e a arte, é buscar a unidade na diversidade e a ordem na complexidade. Sua incumbência final é encaixar a multiplicidade de elementos numa espécie de esquema compacto, coerente e compreensivel (BERLYNE apud STORR, 2002, p. 211).

Storr admite que a percepção de uma melodia como algo contínuo é uma ilusão, da mesma forma como a atividade mental também não é. A progressão ordenada e coerente do pensamento e da melodia é um falseamento retrospectivo do que ocorre na realidade. Nossos pensamentos chegam a um destino seguindo um caminho tortuoso e para que possamos recordá-los, precisamos criar padrões coerentes. Essa atividade mental desenvolve-se em todo individuo e está presente até nos padrões intelectuais mais abstratos. Tanto a música como a matemática se ocupam de relações abstratas e conseguem produzir padrões coerentes a partir dessas ideias. Ambas atraem nossos sentidos, só que a música, diversamente da matemática, interage sobre nossas emoções. Ela é capaz de promover estimulações fisiológicos, tendo em vista que os sons se consubstanciam em formas de comunicação emocional. Desta maneira, tanto intelectual como emocionalmente ela restabelece a conexão entre a mente e o corpo, por isso, a música conecta-se mais intensamente com o fluxo da vida sensível. Na sua 
trajetória, ela trabalha com o movimento interno do homem, tanto físico como psíquico:

Al afirmar que una pieza musical nos conmueve, queremos decir que nos estimula, que nos afecta físicamente. La participación corporal siempre implica algún tipo de movimiento, ya se trata de tensión muscular, balanceo, cabeceo rítmico, llanto o vocalización. [...] El hecho de moverse y el de sentirse conmovido está relacionado de forma inseparable, tanto en el campo semántico como en la realidad externa [...] La gran música siempre expresa algo que trasciende lo personal porque depende de un proceso de ordenación interna que es, en grande parte, inconsciente y que, por tanto, no há sido dispuesto de forma deliberada por el compositor. [...] Los grandes logros creativos del ser humano son producto de su cerebro, pero ello no implica que sean elaboraciones del todo conscientes (lbid, 230-233).

autor deixa claro que as pessoas que recebem uma educação musical adequada em sua infância integram-se mais apropriadamente à vida (Ibid, p. 161-164), corroborando o pensamento de H. Gardner.

compositor lgor Strawinsky também admite que a ação musical em última essência é organizacional. Ele descarta o fato de que o simples contato com os elementos sonoros transforma o indivíduo em um músico. Só quando o homem transforma as vozes da natureza em música é que ele consegue participar ativamente dos processos de ordenamento e criação da mente:

Deduzco, pues, que los elementos sonoros no constituyen la música sino al organizarse, y que esta organización presupone una acción consciente del hombre [...] Reconozco la existencia de sonoridades elementales, del material musical en estado bruto, agradables por sí mismas, que acarician el oído y aportan un placer que pude ser completo. Pero por encima de este goce pasivo vamos a descubrir la música que nos hace participar activamente en la operación de un espíritu que ordena, que vivifica y que crea, puesto que en el origen de toda creación se descubre un deseo que no es el de las cosas terrestres. Así 
es que a los dones de la naturaleza se vienen a añadir los beneficios del artífice. Tal es la significación general del arte. [...] El arte, en sua exacta significación, es una manera de hacer obras según ciertos métodos obtenidos, sea por aprendizaje o por invención. Y los métodos son los caminos estrictos y determinados que aseguran la rectitud de nuestra operación (STRAUINSKY, 1986, p. 27-28).

Da mesma maneira, o psicólogo Daniel J. Levitin, em capítulo publicado (ILARI, 2006), admite que uma das maiores necessidades humanas é encontrar padrões de todos os tipos no ambiente. $\bigcirc$ cérebro humano constantemente tenta pôr ordem na desordem e a música é um jogo de padrões fantástico para os nossos centros cognitivos superiores. Nela os padrões emergem, reagrupam-se, se repetem e se dobram sobre si mesmos de muitas maneiras interessantes. Levitin relata que a escuta musical é capaz de ativar as estruturas neurais profundas localizadas nas regiões primitivas do cérebro, o vermis cerebelar (portal das emoções), desde que considerados três aspectos fundamentais desta arte: o seu poder de comunicação, a expectativa e o tempo musical.

Para ele a prosódia, o ritmo e o contorno musical podem provocar nos indivíduos um eco evolucionário de comunicação primitiva e os mecanismos neurais primitivos de temporização. $\bigcirc$ ritmo musical sensibiliza o homem, pois, de todas as atividades humanas, a música é a que tem a maior regularidade temporal e o tempo é a propriedade mais fundamental que se aprende no condicionamento e na habituação. $\bigcirc$ texto de músico Dieter Schnebel corrobora as afirmativas de Levitin:

[...] a música se baseia por um lado em tom (som) e ritmos e por outro lado em repetição no mais amplo sentido mais exatamente: em relações por meio de repetição como uma busca de volta para o momento presente. Logo, a periodização pertence à essência original da música, pois tanto tom e ritmo quanto repetição implicam em uma vibração regular. Vendo-se grosseiramente, a música pode parecer uma sequência de períodos onde as frequências dos eventos sonoros na microesfera e sua rítmica na macroesfera são estruturadas, compondo na totalidade, um tempo moldado (SCHNEBEL. In: KATER, 1994, p. 2). 
Outra relação profunda da música com o ser humano está na ligação que ela estabelece com o corpo. O texto de José Carlos Godinho (In: ILARI, 2006, p. 353-379) descreve a importância do corpo na aprendizagem e na representação da música. A associação entre música e corpo está presente não só nas atividades de produção musical, mas também na mente humana. A criança sente a música na ação, considerando-se que ela aprende muito mais fazendo. Ele reafirma as ideias do pedagogo musical Émile Jaques-Dalcroze ao relatar que todo corpo deve ser posto em movimento rítmico e que a partir dele, as crianças começam a pensar e se expressar de forma mais musical. É nesse contato que os indivíduos desenvolvem, de forma criativa, seu potencial emocional, cognitivo e físico:

Ao formar uma consciência rítmica, o aluno passará a apreciar as durações e a sua notação; os seus músculos respiratórios, completamente treinados, estarão inteiramente sob controle e ele estará preparado para assumir, sem riscos para a sua voz, o estudo da tonalidade. Quando o sentido tonal, por sua vez, tiver sido formado através de exercícios diários de ouvido e voz, será então o momento, e não antes, de passar aos estudos instrumentais (JACQUES DALCROZE apud CODINHO. In: ILARI, 2006, p. 357).

Pedagogos musicais como Carl Orff, Zoltan Kodály e Justine Ward demonstraram em suas metodologias a importância do movimento para a compreensão musical e o desenvolvimento global da criança. Carl Orff expressava os padrões rítmicos, formados a partir de padrões verbais retirados de rimas e canções, por movimentos corporais (palmas, batimentos de pés e pernas, estalos com os dedos, corrida, saltos, passos). Só depois esses padrões eram transferidos para os instrumentos.

Kodály, da mesma forma, utilizou movimentos e jogos musicais para ensinar música para as crianças, independentemente do canto nas aulas. Os gestos das mãos tiveram grande importância em sua metodologia de ensino, eles identificavam as notas para a condução do canto.

J. Ward, por sua vez, utilizou os gestos das notas em níveis corporais para designar a altura dos sons e os níveis de altura especiais (peito, queixo, nariz, testa, por cima da cabeça). Mais tarde John Paynter 
e Murray Schafer valorizaram a expressão livre e a criatividade dos estudantes. A expressão corporal passa a ser focada como uma atividade essencial para o desenvolvimento da expressividade, da sensibilidade, da imaginação e da criatividade, mesmo não fazendo uso de uma sistematização adequada para os programas de ensinoaprendizagem musical.

Godinho, no texto acima citado, relata que a mente musical se traduz em um complexo de informações sobre as transformações do corpo na interação com os objetos e acontecimentos musicais, sendo que esse complexo multidimensional que se ativa no cérebro informa os estados dos objetos musicais percepcionados, bem como os estados do nosso próprio corpo. As imagens mentais que construímos da música são um misto de música e de nós próprios (CODINHO. In: ILARI, 2006, p. 368), portanto, envolve aspectos relacionados à subjetividade humana.

Em igual dimensão, o regente e pianista Daniel Barenboim (2008) entende a subjetividade como uma parte inevitável da música, ainda que não a única. Apesar de se expressar pelo som, ela pode estabelecer significados diferentes para cada pessoa ou até para a mesma pessoa em momentos distintos:

El poder de la música radica en su capacidad de dirigirse a todos los aspectos del ser humano: animal, emocional, intelectual y espiritual. A menudo pensamos que las cuestiones personales, sociales y políticas son independientes, que nos se influyen una a outra. La música nos enseña que esto es una impossibilidade objetiva; simplesmente no hay elementos independientes. El pensamento lógico y las emociones intuitivas deben estar permanentemente unidos. La música, en suma, nos enseña que todo está relacionado (BARENBOIM, 2008, p. 137).

$\bigcirc$ músico Michael P. Steinberg também admite que música retrata a subjetividade humana, ainda que seja uma prática discursiva abstrata, afastada do mundo da representação. Ele admite que ao partilhar esta subjetividade no momento da execução, a música anuncia contextos e dependências histórico-culturais presentes no mundo, que levam à criação de uma estética musical que se estabelece na comunicação coletiva que ela promove. Por esta perspectiva entendemos que 
Steinberger admite a contribuição das emoções na formação de estilos musicais que norteiam os processos de execução, composição e escuta musical. Tal possibilidade enriquece as perspectivas de um ensino musical voltado para a percepção e apreciação musical, já que de forma abstrata, a subjetividade vai compondo um ideário estético:

\begin{abstract}
[...] el acto de escuchar música ocorre al mismo tempo que la música (investida con la ficción de la subjetividad) escucha y razona; escuchar para poder razonar, para aprender el arte (político) de la subjetividad [...] Si oímos y compreendemos que la música siente y piensa, la estaremos entendendo como un modo de subjetividad antes que como un objeto, un "objeto artístico", o llegado el caso, una "obra de arte" (STEINBERC, 2008, p. 32-33).
\end{abstract}

Steinberg considera que a música tem a capacidade de organizar a subjetividade e esta capacidade é tanto formal como cultural. Ela não está nem no intérprete, nem no compositor, nem no ouvinte, mas na própria música que tem capacidade mnemônica, sensação do passado e futuro e uma linguagem que the permite articulá-la: "La autoconciencia de la música reside en la ficción de que la música escucha: a sí misma, su passado, sus deseos" (STEINBERC, 2008, p. 32).

L. Meyer (2005) complementa as ideias de Steinberg, quando discute a combinação complexa que se estabelece entre a linguagem musical de cunho abstrato e a experiência emocional e estética que essa linguagem abriga:

[...] la música origina afecto a través de la mediación de la connotación consciente o de los processos de imagen inconscientes. Un suspiro, un sonido o una fragancia evocan recuerdos semiolvidados de personas, lugares y experiências, agitan los sueños "mesclando el recuerdo con el deseo", o dispiertan connotaciones conscientes de objetos referenciales. Estas imágenes, sean conscientes o inconscientes, son los estímulos a los que se da realmente una repuesta afectiva. En suma, la música puede dar lugar a imágenes y series de pensamentos que, debido a su relación con la vida interior de cada indivíduo, pueden culminar finalmente en afecto (MEYER, 2005, p. 26 I). 
Esse pesquisador admite que as pesquisas que estudam a resposta emocional da música com relação aos estímulos recebidos ainda são precárias, pois estão baseadas em testemunhos introspectivos dos ouvintes, compositores, intérpretes e críticos. Não há experiências científicas capazes de solucionar esta problemática; muito pouco se sabe da natureza dessas respostas ou sobre a conexão causal que existe entre o estímulo musical e a resposta efetiva que ela provoca nos ouvintes. Vejamos o seu relato:

Desde Platón hasta los estúdios más recientes sobre la estética e el significado de la música, los filósofos y críticos han afirmado, con pocas excepciones, su creencia en la capacidad de la música para suscitar respuestas emocionales en los oyentes. La mayor parte de los tratados sobre composición e interpretación musical insisten en la importância de la comunicación de los sentimentos y de la emoción. Los compositores han demostrado, tanto en sus escritos como por médio de los signos de expresión utilizados en sus partituras, su fe en el poder afectivo de la música. Y, finalmente, los oyentes de ayer y de hoy han afirmado con notable regularidade que la música despierta en ellos sentimentos y emociones (lbid, p. 28).

Meyer relata que muitas experiencias afetivas atribuidas diretamente a estímulos musicais tanto podem ser produto de processos inconscientes de imagens como de processos conscientes de produção de imagem - quando o ouvinte tem consciência das associações que promove enquanto escuta o texto musical. Nos processos inconscientes de produção de imagem, torna-se impossivel qualquer reflexão, pois elas são desconhecidas até pelo indivíduo que promove as imagens, daí sua pesquisa se concentrar apenas nos processos conscientes de produção de imagens (LIMA, 2013, p. 138).

J. Sloboda também tem se consagrado como um pesquisador importante no campo da Psicologia Cognitiva da Música. Em trabalhos publicados ele nos leva a refletir sobre o fator emocional presente na música e como essas emoções se inter-relacionam entre os indivíduos e as diversas culturas: “[...] o fator emocional é intercultural. Não se explicaria que a música tenha penetrado até a base de tantas culturas diferentes, se não existisse alguma atração humana fundamental pelo som organizado que transcende as barreiras culturais" (SLOBODA, 2008, p. 3). 
Ele admite que independentemente da sua estrutura formal, a linguagem musical traz à tona sentimentos e emoções individuais presentes nas mais diversas culturas e em diferentes perspectivas. Seguindo em parte o pensamento de Michael P. Steinberg, Sloboda entende que neste expressar coletivo, a música vai assumindo padrões estéticos específicos a um determinado momento histórico e a um determinado povo, mesmo se considerando que ela veicula pensamentos não representativos e não verbalizados. Dessa forma, ela contém uma historicidade e um destino cultural projetado pelos indivíduos e pelas condições territoriais em que ela se insere. Como relata Enrico Fubini:

La música es, en efecto, un arte típicamente "social"; se há ido gestando, a lo largo de su historia, conforme as exigencias de carácter extramusical, de acuerdo con unos fines que cumplir, en la esfera pública, muy precisos [...] el arte musical presenta mil engranages de carácter social, se inserta profundamente en la colectividad humana, recibe múltiples estímulos ambientales y crea, a su vez, nuevas relaciones entre los hombres (FUBINI, 2001, p. 163-164).

Além desse caráter sociocultural, Sloboda, assim como Storr e Roederer, pensa a linguagem musical como promotora da ordem. Roederer, por exemplo, preocupado em estudar como a música atua no cérebro humano, não menosprezou o poder ordenatório desta arte e nem sua função cultural: "Em quase todas as culturas, a música consiste em sucessões e superposições organizadas e ritmicamente estruturadas de sons selecionados a partir de um repertório muito limitado das alturas discretas de uma determinada escala" (ROEDERER, 1998, p. 33).

Tanto Sloboda como Roederer admitem que a música transcende a intenção hegemônica que as culturas dominantes intentam impor aos individuos. Mesmo diante do fenômeno da globalização as sociedades não se anulam ou desaparecem, e o sujeito, tampouco se apresenta passivo ou desmobilizado neste novo cenário, dando continuadamente sinais da sua singularidade.

Sloboda também admite que a forma e o conteúdo, embora relevantes para determinar o valor emocional de uma música também são diferenciadas de uma cultura para outra, quando não pelos ouvintes de uma mesma cultura. $\bigcirc$ caráter emocional de uma obra musical 
não é unitário e muito menos imutável por natureza. Nossa resposta emocional para uma determinada música pode variar em muito de uma audição para outra, independentemente de sabermos previamente o que o compositor daquela obra quer expressar. Assim, o mesmo contexto musical pode receber de um ouvinte uma leitura emocional diferente de outro ouvinte que detenha as mesmas capacidades e habilidades musicais. A mente humana nem sempre leva o individuo a desenvolver determinado tipo de emoção:

Considerando que as habilidades musicais são transmitidas culturalmente, segue-se que elas variam significativamente de uma cultura para outra. Muitos estudiosos da psicologia da música falam sobre a música tonal do ocidente como se esta fosse única. Embora minha ignorância não permita falar muito a respeito da música de outras culturas, [...] o capítulo 7 (do livro em questão) contém uma tentativa de avaliar até que ponto alguns princípios cognitivos, que subjazem às habilidades musicais ocidentais, são relevantes para outras formas de música. Grande parte do pensamento contemporâneo em psicologia cognitiva é funcional, já que tenta descobrir os principios estruturais e operacionais que permitiriam a um sistema que lida com informações, comportar-se da maneira que observamos no comportamento humano. Porém, é preciso termos em mente que estes principios têm existência de fato, em nosso caso, nas estruturas e funções do cérebro, e que vale a pena descobrirmos o que for possível sobre o cérebro no que concerne às habilidades examinadas (SLOBODA, 2008, p. 10-11).

Sloboda admite que muitas experiências no campo da psicologia cognitiva da música já comprovaram que diversos componentes de habilidades musicais aparentam ter uma localização específica no cérebro: "a organização funcional do cérebro é modular, com partes específicas realizando tarefas específicas" (Ibid, p. 11). Entretanto, ele admite que determinados padrões significativos de comportamento pensante são aprendidos na interação com a cultura e são específicos a cada cultura em particular: “ [...] há poucas evidências de que exista um único "centro musical" no cérebro. [...] as áreas do cérebro responsáveis pela música parecem ter alguma sobreposição parcial, porém incompleta, com as áreas responsáveis pela linguagem. [...] A 
música, se não faz uso de uma função neural totalmente distinta, quase certamente faz uso de uma configuração diferenciada dos recursos neurais (Ibid, p. 349).

Muito ainda poderia ser dito sobre a função, sentido e utilidade da música na formação e desenvolvimento humano, contudo, os relatos aqui produzidos comprovam cabalmente que a música é capaz de contribuir e trazer para os indivíduos maior desenvolvimento psíquico, social, físico e mental, o que de certa maneira, comprova a sua importância como área de conhecimento que deve integrar a matriz curricular da educação básica, do ensino informal, e dos cursos superiores de formação de docentes, sob variantes distintas interconectadas às necessidades socioculturais, físicas e psicológicas dos indivíduos. Somente nessas condições o ensino musical pode extrapolar e transcender o uso puramente tecnicista que até então foi atribuido.

\section{Referências}

BARENBOIM, Daniel. El sonido es vida: el poder de la música. Trad. Dolors Udina. Bogotá: Norma, 2008.

FUBINI, Enrico. Música y linguaje en la estética contemporânea. Madrid: Alianza Música, 2001.

CARDNER, Howard. Estruturas da mente: a teoria das inteligências múltiplas. Trad. Sandra Costa. Porto Alegre: Artes Médicas Sul, 1994.

CODINHO, José Carlos. O corpo na aprendizagem e na representação mental da música. In: ILARI, Beatriz (Org). Em busca da mente musical: ensaios sobre os processos cognitivos em música - da percepção a produção. Curitiba: Ed. da UFPR, 2006, p. 352-379.

KATER, Carlos (Org). Cadernos de Estudo: educação musical. Belo Horizonte: Atravez/ EMUFMC/FEA/FAPEMIC, 1997. 
LEVITIN, Daniel J. Em busca da mente musical. P. 23- 44. In: ILARI, Beatriz ( org). Em busca da mente musical: ensaios sobre os processos cognitivos em música- da percepção a produção. Curitiba: Ed. da UFPR. 2006.

LIBÂNEO, José Carlos; SANTOS, Akiko (Orgs). Educação na era do conhecimento em rede e transdisciplinaridade. Campinas: Alínea, 2005.

LIMA, Sonia R, Albano. Performance: investigação hermenêutica nos processos de interpretação musical. In: RAY, Sonia (Org). Performance musical e suas interfaces. Goiânia: Editora Vieira, 2005, p. 91-114.

LIMA, Sonia R. Albano. (Org). Uma leitura transdisciplinar do fenômeno sonoro. São Paulo: Editora Som: Faculdade de Música Carlos Comes, 2007.

LIMA, Sonia R. Albano. A dimensão comunicativa da linguagem musical. In: SEVERINO, Francisca Eleodora Santos; LIMA, Sonia Regina Albano de (Orgs.). Mosaicos: Arte, Cultura e Educação. São Paulo: Editora Todas as Musas, 2011, p. 17-42.

MEYER, Leonard B. La emoción y el significado en la música. Trad. José Luis Turina de Santos. Madrid: Alianza, 2005.

MORAES, Maria Cândida. Ecologia dos Saberes: complexidade, transdisciplinaridade e educação: novos fundamentos para iluminar novas praticas educacionais. São Paulo: Antakarana/ WHH-Willis Harman House, 2008.

ROEDERER, Juan G. Introdução a física e psicofísica da música. Trad. Alberto Luis da Cunha. São Paulo: EDUSP, 1998, p. 17-34.

SCHNEBEl, Dieter. $\bigcirc$ som faz a música ou: contra a idiomatização! In: Kater, Carlos. Cadernos de Estudo. Análise Musical 6/7. São Paulo: Atravez, fev. 1994, p. 1-6. 
SLOBODA, John A. A mente musical: psicologia cognitiva da música. Trad. Beatriz llari e Rodolfo llari. Londrina: EDUEL, 2008.

STEINBERG, Miachael P. Escuchar a la razón: cultura, subjetividade y la música del siglo XIX. Trad. Teresa Arijón. Buenos Aires: Fondo de Cultura Económica, 2008.

STORR, Anthony. La música y la mente: el fenomeno auditivo y el porqué de las pasiones. Trad. Verônica Canales Medina. Barcelona: Paidós Ibérica, 2002.

STRAUINSSKY, Igor. Poética Musical. Trad. Eduardo Grau. Madrid: Taurus, 1986.

\section{Sobre a autora}

Sonia Regina Albano de Lima é Presidente da Associação Nacional de Pesquisa e Pós-graduação em Música (ANPPOM), gestão 2015-2017. Doutora em Comunicação e Semiótica - Artes da PUC/SP, Pós doutora pelo IA-UNESP. Bacharel em Direito pela USP. É professora da Pós-Graduação em Música do IA- UNESP desde 2004. Possui diversas publicações na área de educação musical, performance e interdisciplinaridade. É líder de pesquisa do CEPEMIA-UNESP e pesquisadora do CEPI-PUC SP. Foi professora e diretora da Faculdade de Música Carlos Gomes e da Escola Municipal de Música de São Paulo. 